Article

\title{
Ecotypes of Aquatic Plant Vallisneria americana Tolerate Different Salinity Concentrations
}

\author{
Mohsen Tootoonchi * ${ }^{\mathbb{D}}$, Lyn A Gettys, Kyle L Thayer, Ian J Markovich, Joseph W Sigmon and \\ Shabnam Sadeghibaniani \\ Fort Lauderdale Research and Education Center, University of Florida, 3205 College Ave., Davie, FL 33314, USA; \\ lgettys@ufl.edu (L.A.G.); kthayer25@ufl.edu (K.L.T); ijmarkovich@ufl.edu (I.J.M); jsigmon@ufl.edu (J.W.S.); \\ shabnam@ufl.edu (S.S.) \\ * Correspondence: m.tootoonchi@ufl.edu; Tel.: +1-786-620-8544
}

Received: 13 December 2019; Accepted: 4 February 2020; Published: 6 February 2020

check for updates

\begin{abstract}
Increased salinity caused by saltwater intrusion or runoff from de-icing salts can severely affect freshwater vegetation and deteriorate aquatic ecosystems. These habitats can be restored with freshwater ecotypes (locally adapted populations) that tolerate above-normal salinity. Vallisneria americana is a prominent species in many freshwater ecosystems that responds differently to abiotic conditions such as substrate composition and fertility, so, in this study, we evaluated the effects of salt stress on 24 ecotypes of $V$. americana. Instant Ocean aquarium salt was used to create saline solutions ( 0.2 to 20.0 parts per thousand (ppt)), then plants were abruptly exposed to these solutions and maintained in these concentrations for five weeks before being visually assessed for quality and destructively harvested. Analysis of variance and nonlinear regression were used to calculate $\mathrm{LC}_{50}$ values-the lethal concentration of salt that reduced plant biomass and quality by $50 \%$ compared to control treatment. Growth rate and visual quality varied significantly among ecotypes, and ecotypes that were most and least sensitive to salt had $50 \%$ biomass reductions at 0.47 and $9.10 \mathrm{ppt}$, respectively. All ecotypes survived $10.0 \mathrm{ppt}$ salinity concentration but none survived at $20.0 \mathrm{ppt}$, which suggests that the maximum salinity concentration tolerated by these ecotypes is between 15.0 and $20.0 \mathrm{ppt}$.
\end{abstract}

Keywords: aquatic macrophytes; freshwater systems; salinity tolerance; intraspecific variation; lethal concentration; genotypic variability; ecotype; salt stress; effective concentration; growth rate; health condition; visual screening

\section{Introduction}

Local adaptation is a well-established phenomenon that is driven by natural selection and may result in plant ecotypes that are adapted to stresses in different habitats [1]. By definition, a distinct form of a plant species that occupies a particular ecosystem or habitat is called an ecotype. Intraspecific variation or ecotypic variability in salt tolerance has been investigated in several plant species [2-5]. For example, different ecotypes of Spartina patens from the Gulf Coast of the United States reportedly tolerate different salinity concentrations [3]. Such differences are the result of local adaptations and originate from genotypic traits as opposed to non-heritable acclimation to adverse conditions. Selection of ecotypes that are capable of tolerating extreme salinity conditions is important and useful in developing strategies for stabilization and revegetation of deteriorating marshes and wetlands that are subject to saltwater intrusion [6,7].

Vallisneria americana is a key species in many aquatic ecosystems [8-12]. This perennial submersed macrophyte provides food and habitat for fish, mammals, and invertebrates and affects nutrient cycling, sediment stability, and water clarity in lakes and estuaries [13]. Gettys and Haller [14] reported that $V$. americana ecotypes differ in their substrate and nutrient requirements, so variability in salt 
tolerance reported for this plant might also be due to ecotypic differences. The species is found in fresh and brackish water, but sporadic high salinity events could induce salt stress in this plant and affect its growth and establishment. Sporadic salinity can occur due to elevation difference from natural saline systems such as the ocean, and such prolonged flooding can have a direct influence on plant survival [15]. Various studies have shown that V. americana can tolerate 5.0 to 15.0 parts per thousand (ppt) salinity [8]. Salt-tolerant ecotypes of $V$. americana could be useful for restoration of wetlands that are at risk of saltwater intrusion and estuaries that are threatened by sea level rise. In addition, the ability to assess salt sensitivity among ecotypes can be used to increase our understanding of the physiological and biochemical mechanisms underlying salt tolerance.

In this study, we used $V$. americana ecotypes that were collected from various locations within Florida, USA. The exact provenance of some of these ecotypes is unknown; however, phenotypic differences were evident and ecotypes varied somewhat in leaf size (i.e., width and length) and leaf color (light green to reddish brown).

In this study, we aimed to answer the following questions:

1. How are Florida ecotypes of V. americana impacted by increased salinity?

2. Is there variability in salt tolerance among V. americana ecotypes?

This study will provide information regarding what salinity levels are lethal to V. americana and will elucidate the relationship between ecotype and salt tolerance, which could yield valuable information to facilitate plant selection for better management of lakes, restoration of estuarine systems, and revegetation of littoral zones endangered by saltwater intrusion.

\section{Materials and Methods}

A total of 24 different $V$. americana ecotypes were gathered from various regions in Florida (Figure 1) and maintained in culture at the University of Florida IFAS Ft. Lauderdale Research and Education Center in Davie, FL, USA. Field-collected plants used for ecotype assessments should be maintained in culture to eliminate field acclimations and subsequent (cultured) generations should be used for experimentation $[5,16]$. All ecotypes were vegetatively propagated and maintained as isolated cultures in a greenhouse under irrigation water $(0.2 \mathrm{ppt})$ for a minimum of five years prior to these experiments to remove environmental influences and acclimations of collection sites.

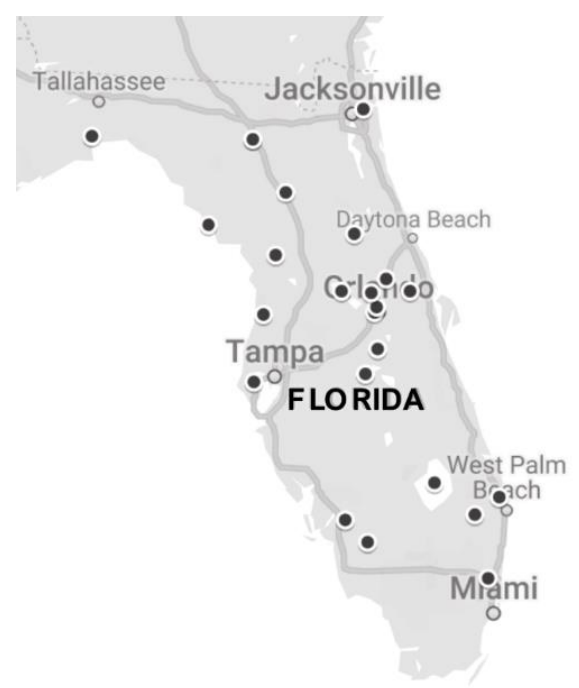

Figure 1. Twenty-four ecotypes of Vallisneria americana were collected from various locations within the state of Florida. Each circle $(\bullet)$ represents the approximate collection site.

Plastic 0.4 L (14 oz) containers were filled with coarse silica sand (Banaszak Concrete Corporation, Davie, FL, USA), and amended via incorporation of $2.0 \mathrm{~g}$ per container of controlled-release fertilizer 
(Osmocote Plus $15 \mathrm{~N}: 9 \mathrm{P}_{2} \mathrm{O}_{5}: 12 \mathrm{~K}_{2} \mathrm{O}$ formulated for 220-day release; ICL Specialty Fertilizers, Dublin, $\mathrm{OH}, \mathrm{USA}$ ). Filled containers were planted with a single 12 to $15 \mathrm{~cm}$ long plant of V. americana, and 24 containers were prepared for each ecotype to provide four replications per salinity level. Planted containers were allowed to grow and establish for four weeks in six separate $1700 \mathrm{~L}$ high density polyethylene tanks filled with irrigation water (salinity $0.2 \mathrm{ppt}$ ) and kept in the greenhouse for four weeks to allow establishment of plants. After four weeks, Instant Ocean aquarium mix (Spectrum Brands Company, Cincinnati, OH, USA), was used to mimic natural seawater salinity. This aquarium salt mix has a complex elemental composition and contains macro and micronutrients (see full chemical analysis at https://doi.org/10.1007/s10452-019-09692-6, [17]) The aquarium salt mix was added to each tank to reach target salinity levels of 2.0, 4.0, 10.0, 15.0, and $20.0 \mathrm{ppt}$. An untreated control tank was not treated with salt but instead retained the natural irrigation water salinity of $0.2 \mathrm{ppt}$. Additional irrigation water was added to all tanks as needed to compensate for evaporation and to maintain salinity levels within $\pm 0.7 \mathrm{ppt}$ of the target level. Data loggers (HOBO Water Temperature Pro v2 Data Logger-U22-001, Onset HOBO Data Loggers, Bourne, MA, USA) were placed in four randomly selected tanks to record water temperature for the duration of the experiment. Salinity and $\mathrm{pH}$ of all six mesocosms were monitored weekly using a portable TDS/conductivity meter (Oakton Con 110, Oakton Instruments, Vernon Hills, IL, USA) and a handheld $\mathrm{pH} / \mathrm{mV} /$ thermometer (IQ 150, Spectrum Technologies, Inc., Plainfield, IL, USA), respectively.

After five weeks of salinity exposure, all plants were individually evaluated by three trained individuals and assigned a visual quality score on a 0 (complete plant death) to 10 (no visible damage) scale (Table A1). All live aboveground biomass was then destructively harvested; plant material was rinsed to remove algae and other debris and placed in a forced-air oven at $65^{\circ} \mathrm{C}$ for two weeks before weighing to obtain dry weights. Mean daily growth rate was evaluated by the method adapted from Hunt [18]:

$$
\text { Growth rate }=(D W 2-D W 1) /(T 2-T 1),
$$

in which DW1 refers to total dry weight of sample at the beginning of the experiment $(\mathrm{T} 1=0)$, and DW2 after the final harvest $(\mathrm{T} 2=35)$. For measuring the initial biomass (DW1), four extra pots of each ecotype were harvested at the start of the experiment before increasing salinity levels. A two-way analysis of variance was used to analyze growth rate and visual rating of ecotypes under increased salinity. Salinity treatments and ecotypes were considered as fixed factors and the effect of each factor was presented separately. Tukey-Kramer was performed where significant differences were detected $(p<0.05)$.

Lethal concentration $\left(\mathrm{LC}_{50}\right)$ is the salinity concentration that reduces plant biomass and visual quality by half compared to the salinity concentration where plants had the best performance (in these experiments, $2.0 \mathrm{ppt}$ ). A nonlinear regression function was used to fit visual quality and dry weight (DW2) of each ecotype along the salinity gradient using an exponential decay model explained by Archontoulis and Miguez [19]. $\mathrm{LC}_{50}$ estimates for visual rating $\left(\mathrm{LC}_{\mathrm{v}}\right)$ and dry weight $\left(\mathrm{LC}_{\mathrm{d}}\right)$ data sets were calculated using the method described by Moore and Caux [20] and Gettys and Haller [21]. Based on $\mathrm{LC}_{50}$ values, ecotypes were considered different if their $95 \%$ confidence intervals (CI) did not overlap. Nonlinear regression can be legitimately used for estimating $\mathrm{LC}_{50}$ values if the experimental design includes adequate coverage of the response range for treatments (i.e., different salinity levels) and having more than five treatments that include lethal and sublethal concentrations increases the likelihood of having an accurate regression [20,22]. In this study, we had six salinity levels which would provide a good response range for the regression; however, at $2.0 \mathrm{ppt}$, ecotypes had better visual quality and produced larger biomass than $0.2 \mathrm{ppt}$. Inclusion of $0.2 \mathrm{ppt}$ in the regression curve would cause overestimation of $\mathrm{LC}_{50}$ estimates. Therefore, $0.2 \mathrm{ppt}$ was removed and $2.0 \mathrm{ppt}$ was considered the control treatment for $\mathrm{LC}_{50}$ analyses, so our treatments were decreased to five salinity levels instead of $6(0.2,2.0,4.0,10.0,15.0$, and $20.0 \mathrm{ppt})$. Statistical analysis was performed using JMP ${ }^{\circledR}$ Pro 14.0.1 (SAS Institute Inc., Cary, NC, USA). 
To provide an overall ranking of the relative performance of ecotypes under the salinity treatments, ecotypes were numerically ranked from "best" to "worst" based on visual rating, growth rate, $\mathrm{LC}_{\mathrm{v}}$ and $\mathrm{LC}_{\mathrm{d}}$. The mean of these five ranking values was then calculated for each ecotype. Ecotypes with tied mean ranks were given the same overall ranking.

\section{Results}

\subsection{Environmental Conditions}

$\mathrm{pH}$ remained consistent throughout the experiment and ranged from 7.8 to 9.2 with no differences among treatments. Temperature was similar in all four monitored mesocosms and mean temperature ranged from 28.2 to $29.3^{\circ} \mathrm{C}$.

\subsection{Impact of Increased Salinity on V. americana}

Increased salinity significantly affected visual rating of $V$. americana $(p<0.0001$; Table 1). For example, at $0.2 \mathrm{ppt}$, the visual rating averaged 6.7 among all ecotypes, but, at $2.0 \mathrm{ppt}$, visual rating increased to 8.0 on average (Figure 2a). At $10.0 \mathrm{ppt}$, visual rating decreased by $64 \%$ (2.9) compared to $2.0 \mathrm{ppt}$ and at $15.0 \mathrm{ppt}$ most ecotypes were obviously stressed, with an average visual rating of 0.8 . All V. americana ecotypes were eliminated at $20.0 \mathrm{ppt}(0.0)$. Increased salinity also impacted the growth rate of $V$. americana $(p<0.0001$; Table 1$)$. All ecotypes had an average growth rate of $14 \mathrm{mg} \mathrm{day}^{-1}$ at $0.2 \mathrm{ppt}$, but, at $2.0 \mathrm{ppt}$, growth rates were increased by $35 \%$ and averaged $22 \mathrm{mg} \mathrm{day}^{-1}$ among ecotypes (Figure 2b). At $4.0 \mathrm{ppt}$, growth rates decreased to $13 \mathrm{mg} \mathrm{day}^{-1}$ which was similar to the growth rate at the original control treatment $(0.2 \mathrm{ppt})$. At $10.0 \mathrm{ppt}$, growth rate was slightly lower than the control treatment and was on average $10 \mathrm{mg}$ day $^{-1}$. At $15.0 \mathrm{ppt}$, salinity level appeared to be too high for the species and most ecotypes were losing tissue with a rate of $-3 \mathrm{mg} \mathrm{day}^{-1}$ on average.

Table 1. Two-way analysis of variance showing the effect of salinity concentration $(2.0,4.0,10.0,15.0$, and $20.0 \mathrm{ppt}$ ), ecotype (24 different ecotypes) and their interaction on visual rating and growth rate of Vallisneria americana.

\begin{tabular}{ccccc}
\hline Parameter & Source & Df (Degree of Freedom) & F Ratio & Prob $>$ F \\
\hline Visual & Ecotype & 25 & 11.02 & $<0.0001$ \\
Rating & Salinity & 4 & 508.43 & $<0.0001$ \\
$\mathrm{r}^{2}=0.87$ & Ecotype $\times$ Salinity & 100 & 2.95 & $<0.0001$ \\
Growth & Ecotype & 25 & 9.64 & $<0.0001$ \\
Rate & Salinity & 4 & 88.71 & $<0.0001$ \\
$\mathrm{r}^{2}=0.71$ & Ecotype $\times$ Salinity & 100 & 3.33 & $<0.0001$ \\
\hline
\end{tabular}
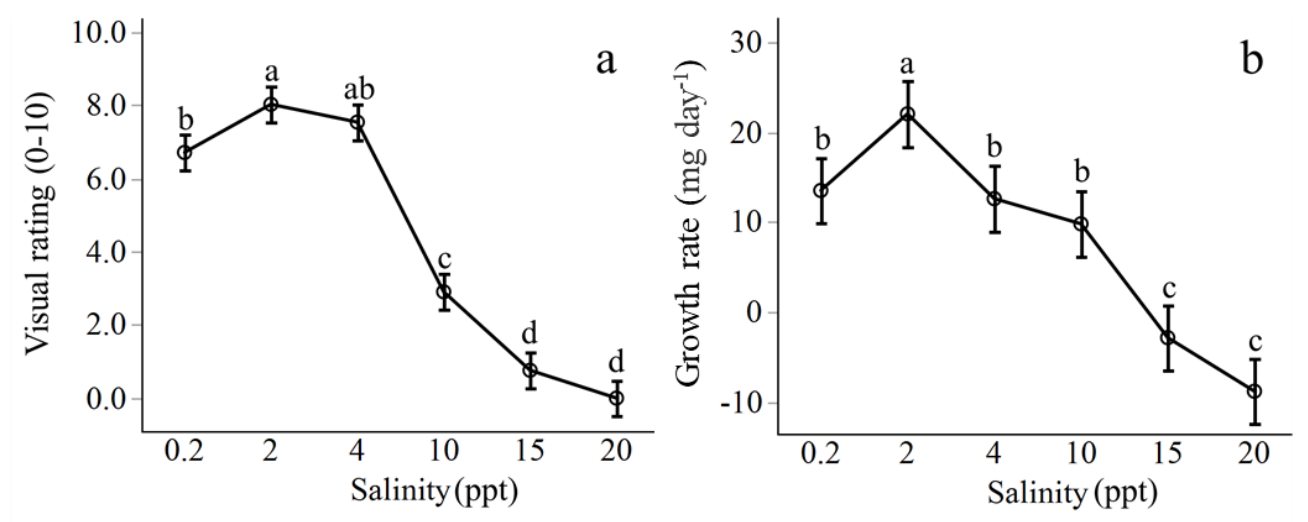

Figure 2. Visual rating (a) and growth rate (b) of Vallisneria americana ecotypes. Each circle and error bar represent 96 observations. Letter differences on top of the bars denote significant $(p<0.05)$ differences among ecotypes. 


\subsection{Variability among V. americana Ecotypes}

Ecotypes of $V$. americana responded differently to increased salinity $(p<0.0001$; Table 1$)$. For example, Bird, Kennedy and Toho ecotypes had the highest visual rating among ecotypes and averaged 6.8, 4.9, and 4.9, respectively (Figure 3a; Table A2). Trafford, Weekie, and Harris had the lowest visual ratings, which averaged 3.3, 3.2, and 2.8, respectively. Bird, George, and Mann had the highest growth rates among ecotypes and averaged 40,16 , and $10 \mathrm{mg} \mathrm{day}^{-1}$, respectively, across the salinity gradient (Figure 3b; Table A2). Ecotypes with the lowest growth rates were Snarrow, Fairview, and Caloosa, which averaged $-1,-5$ and $-5 \mathrm{mg} \mathrm{day}^{-1}$, respectively. Few ecotypes were unaffected by the salinity treatments. For example, visual rating and growth rate of Caloosa, Rainbow, and Snarrow ecotypes did not differ across the salinity gradient $(p>0.05$; Tables A3 and A4). In addition, the growth rates of STA and Suwanee ecotypes were not affected by increased salinity, but their visual ratings differed among salinity levels.
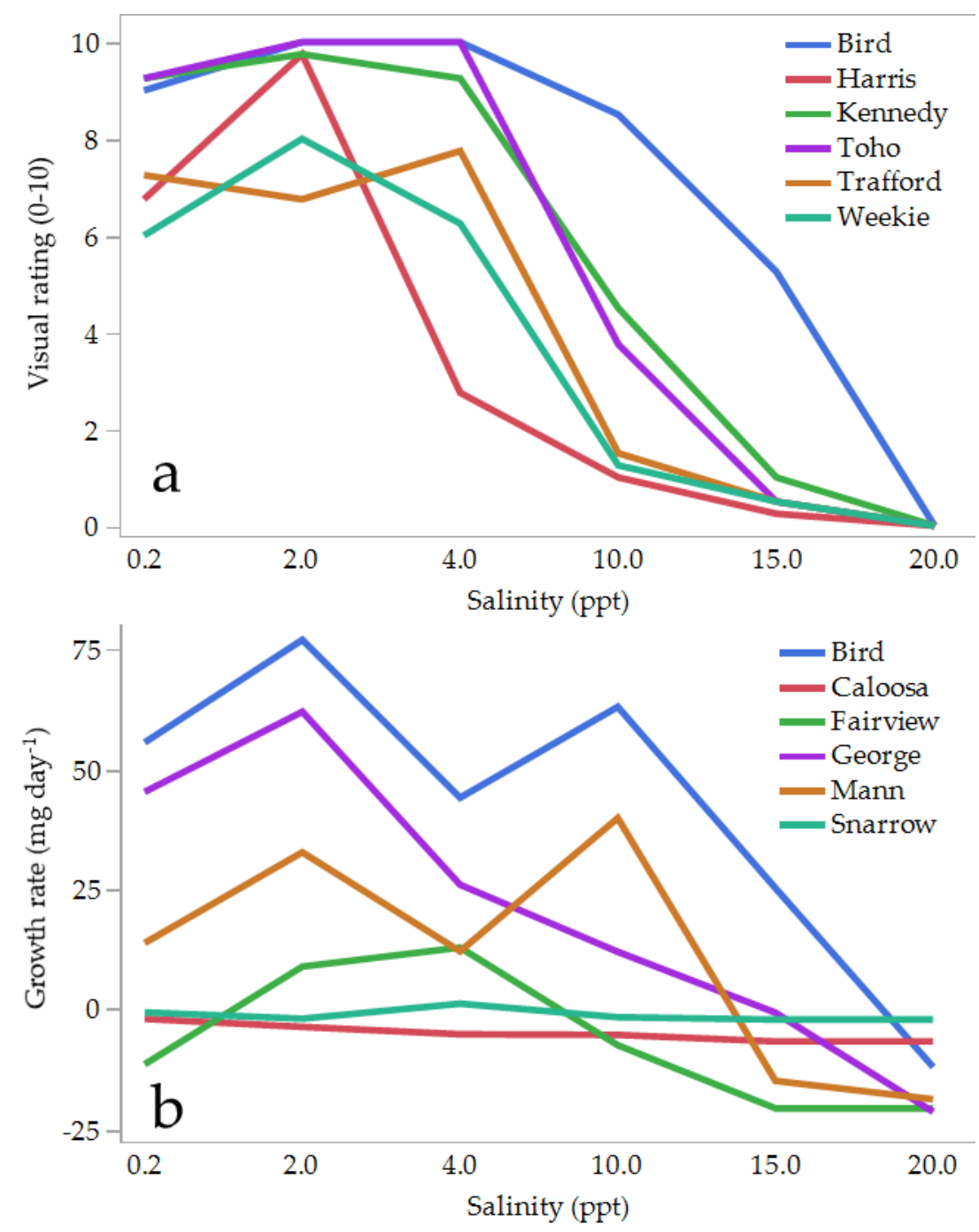

Figure 3. Visual rating and growth rate for subsets of the 24 Vallisneria americana ecotypes along the salinity gradient. Shown are three ecotypes with the highest and lowest (a) visual rating and (b) growth rates. Each line represents 30 observations.

Calculated $\mathrm{LC}_{50}$ values were developed using visual rating and dry weight data. The $\mathrm{r}^{2}$ values revealed that the visual rating was more directly related to increased salinity than dry weight and hence had higher $\mathrm{r}^{2}$ values (Table 2). Bird's visual rating was reduced by $50 \%\left(\mathrm{LC}_{\mathrm{v}}\right.$ ) at a salinity of 
9.00 ppt (lower and upper 95\% CI 6.58 and $14.24 \mathrm{ppt}$, respectively), which was higher than $\mathrm{LC}_{\mathrm{v}}$ values for Feather, George, Harris, Pierce, Toho, and Wekiva. Harris was the most salt-sensitive ecotype and had the lowest $\mathrm{LC}_{\mathrm{V}}$ value (1.13 ppt; lower and upper $95 \% \mathrm{CI} 0.86$ and $1.62 \mathrm{ppt}$, respectively). Based on the $\mathrm{LC}_{\mathrm{d}}$ values, Bird had 50\% reduction in biomass at $9.1 \mathrm{ppt}$ (lower and upper 95\% CI 5.55 and $>20.00 \mathrm{ppt}$, respectively), which was two and three times higher than $\mathrm{LC}_{\mathrm{d}}$ values for Wakulla and Wekiva (Table 2). Feather also had a higher $\mathrm{LC}_{\mathrm{d}}$ value (12.74) than Wakulla and Wekiva. However, $\mathrm{LC}_{\mathrm{v}}$ value for Feather was three times lower than the estimated $\mathrm{LC}_{\mathrm{d}}$ (4.14). Since these two estimations contradicted, Feather may be also a salt sensitive ecotype.

Table 2. Lethal concentration $\left(\mathrm{LC}_{50}\right)$ of salt expected to cause a $50 \%$ reduction in visual rating $\left(\mathrm{LC}_{\mathrm{v}}\right)$ and dry weight $\left(\mathrm{LC}_{\mathrm{d}}\right)$ of Vallisneria americana compared with plants grown at $2.0 \mathrm{ppt}$ saline solution (salinity level with the best plant performance). $\mathrm{LC}_{50}$, upper and lower $95 \%$ confidence interval are calculated based on nonlinear regressions fitted for visual rating and dry weight data. Ecotypes are considered different if their upper and lower confidence intervals do not overlap.

\begin{tabular}{ccccccccc}
\hline Ecotype & LC $_{\mathbf{v}}$ & Lower & Upper & $\mathbf{r}^{2}$ & LC $_{\mathbf{d}}$ & Lower & Upper & $\mathbf{r}^{\mathbf{2}}$ \\
\hline Bird & 9.00 & 6.58 & 14.24 & 0.76 & 9.10 & 5.55 & $>20.00$ & 0.51 \\
Biven & 5.94 & 4.00 & 11.53 & 0.70 & 7.42 & 4.30 & $>20.00$ & 0.45 \\
Mann & 5.48 & 4.12 & 8.16 & 0.86 & 6.65 & 4.03 & 18.95 & 0.57 \\
Rockstar & 5.42 & 3.53 & 11.65 & 0.68 & 9.85 & 4.59 & $>20.00$ & 0.24 \\
Fairview & 5.37 & 3.75 & 9.45 & 0.76 & 4.83 & 2.79 & 18.28 & 0.55 \\
Ballen & 5.35 & 3.98 & 8.17 & 0.84 & 5.34 & 3.76 & 9.19 & 0.76 \\
Kennedy & 5.28 & 4.35 & 6.73 & 0.93 & 3.87 & 2.46 & 9.01 & 0.70 \\
Monroe & 5.06 & 3.56 & 8.77 & 0.78 & 7.22 & 3.82 & $>20.00$ & 0.39 \\
Okeech & 4.78 & 3.37 & 8.20 & 0.80 & 4.78 & 2.83 & 15.28 & 0.57 \\
Toho & 4.64 & 3.71 & 6.19 & 0.92 & 5.72 & 3.68 & 12.77 & 0.65 \\
George & 4.47 & 3.73 & 5.59 & 0.95 & 4.87 & 2.94 & 14.33 & 0.60 \\
Trafford & 4.36 & 2.61 & 13.29 & 0.62 & 5.92 & 3.02 & $>20.00$ & 0.33 \\
STA & 4.30 & 2.99 & 7.63 & 0.80 & NA & NA & NA & NA \\
Harney & 4.29 & 2.88 & 8.45 & 0.76 & 7.33 & 3.60 & $>20.00$ & 0.31 \\
Feather & 4.14 & 3.16 & 6.00 & 0.89 & 12.74 & 5.16 & $>20.00$ & 0.16 \\
Wakulla & 3.81 & 2.46 & 8.50 & 0.69 & 4.68 & 2.25 & $>20.00$ & 0.31 \\
Pierce & 3.76 & 2.84 & 5.58 & 0.89 & 2.62 & 1.16 & 10.39 & 0.39 \\
Suwanee & 3.76 & 2.14 & 15.68 & 0.59 & NA & NA & NA & NA \\
Weekie & 3.45 & 2.20 & 7.94 & 0.74 & 3.11 & 1.83 & 10.44 & 0.66 \\
Wekiva & 2.98 & 1.99 & 5.95 & 0.81 & 2.09 & 1.00 & $>20.00$ & 0.49 \\
Harris & 1.13 & 0.86 & 1.62 & 0.93 & 0.47 & 0.24 & 10.54 & 0.87 \\
Rainbow & NA & NA & NA & NA & NA & NA & NA & NA \\
Snarrow & NA & NA & NA & NA & NA & NA & NA & NA \\
Caloosa & NA & NA & NA & NA & NA & NA & NA & NA \\
\hline & NA Ecotype did not & & & & & \\
Nhow a significant response to & salinity gradient. &
\end{tabular}

To better compare the salinity tolerance of each ecotype, all ecotypes were ranked 1 to 24 from best to worst relative performance (Table 3). This table shows that Bird was ranked 1 and had the highest growth rate, visual rating, and $\mathrm{LC}_{\mathrm{V}}$ value, while Caloosa (ranked 24) had the lowest growth rate and second lowest visual rating, $\mathrm{LC}_{\mathrm{v}}$ and $\mathrm{LC}_{\mathrm{d}}$ values among ecotypes. In fact, Bird was able to survive under $15.0 \mathrm{ppt}$, but Caloosa was decimated after five weeks. Few other ecotypes such as Snarrow, Feather, and STA were also decimated at $15.0 \mathrm{ppt}$, but they were ranked 20.5, 14.5, and 12.5, respectively. Therefore, ranks may not perfectly correspond to the salinity tolerance of ecotypes. 
Table 3. Vallisneria americana ecotypes are ranked based on visual rating, growth rate and lethal concentration $\left(\mathrm{LC}_{50}\right)$ estimated using visual rating $\left(\mathrm{LC}_{\mathrm{v}}\right)$ and dry weight $\left(\mathrm{LC}_{\mathrm{d}}\right)$ models. In each column, ecotypes are ranked from best (1) to worst (24).

\begin{tabular}{cccccccc}
\hline Ecotype & Visual Rating & Growth Rate & $\mathbf{L C}_{\mathbf{v}}$ & $\mathbf{L C}_{\mathbf{d}}$ & Mean Rank & \multicolumn{2}{c}{ Overall Ranking } \\
\hline Bird & 1 & 1 & 1 & 4 & 1.75 & 1 & $\mathrm{~A}$ \\
Mann & 5 & 3 & 3 & 9 & 5 & 2 & $\mathrm{AB}$ \\
Ballen & 4 & 6 & 6 & 12 & 7 & 3.5 & $\mathrm{ABC}$ \\
Toho & 3 & 4 & 10 & 11 & 7 & 3.5 & $\mathrm{ABC}$ \\
Rockstar & 11 & 12 & 4 & 2 & 7.25 & 5.5 & $\mathrm{ABC}$ \\
Monroe & 8 & 5 & 8 & 8 & 7.25 & 5.5 & $\mathrm{ABC}$ \\
George & 6 & 2 & 11 & 14 & 8.25 & 7 & $\mathrm{ABC}$ \\
Biven & 7 & 21 & 2 & 6 & 9 & 8 & $\mathrm{ABC}$ \\
Kennedy & 2 & 9 & 7 & 19 & 9.25 & 9 & $\mathrm{ABC}$ \\
Okeech & 10 & 7 & 9 & 17 & 10.75 & 10 & $\mathrm{ABCD}$ \\
STA & 13 & 15 & 14 & 3 & 11.25 & 11 & $\mathrm{ABCD}$ \\
Trafford & 18 & 8 & 12 & 10 & 12 & 12 & $\mathrm{ABCD}$ \\
Feather & 14 & 20 & 16 & 1 & 12.75 & 13 & $\mathrm{ABCD}$ \\
Fairview & 9 & 23 & 5 & 16 & 13.25 & 14 & $\mathrm{ABCD}$ \\
Harney & 15 & 18 & 15 & 7 & 13.75 & 15 & $\mathrm{ABCD}$ \\
Waqulla & 12 & 11 & 17 & 18 & 14.5 & 16 & $\mathrm{BCD}$ \\
Suwanee & 20 & 16 & 19 & 5 & 15 & 17 & $\mathrm{BCD}$ \\
Pierce & 17 & 13 & 18 & 21 & 17.25 & 18 & $\mathrm{BCD}$ \\
Wekiva & 16 & 10 & 22 & 22 & 17.5 & 19 & $\mathrm{BCD}$ \\
Snarrow & 24 & 22 & 13 & 13 & 18 & 20 & $\mathrm{BCD}$ \\
Rainbow & 22 & 19 & 20 & 15 & 19 & 21 & $\mathrm{CD}$ \\
Weekie & 19 & 17 & 21 & 20 & 19.25 & 22 & $\mathrm{CD}$ \\
Harris & 21 & 14 & 24 & 24 & 20.75 & 23 & $\mathrm{CD}$ \\
Caloosa & 23 & 24 & 23 & 23 & 23.25 & 24 & $\mathrm{D}$ \\
\hline
\end{tabular}

\section{Discussion}

Some researchers have categorized salinity stress in plants into phase one (salt shock or osmotic stress) and phase two (ionic stress) [23,24]. Phase one is caused by short-term exposure to high sodium concentrations, which affects plants through imbalanced osmotic pressure and causes wilting. Phase two of salt stress elicits long-term physiological responses such as reduced growth rate and production of osmo-protectant compounds such as sugars, amino acids, and proteins. In our study, we did not intend to study plant response to the short-term salinity stress (salt shock or phase one) and hence plants were exposed to a five-week period of elevated salinity, long enough to assess long-term plant response such as growth rate.

In this experiment, visual rating and growth rate of most ecotypes were affected by salinity treatments; however, a few ecotypes (Suwanee, Rainbow, Snarrow and Caloosa) did not respond to increased salinity concentrations (Table A3). These ecotypes had very low visual ratings and growth rates regardless of salinity levels; therefore, statistical analysis did not detect significant difference among salinity levels. Results from the visual rating evaluations showed that all ecotypes perished at $20.0 \mathrm{ppt}$, which suggests that this level was higher than tolerable salinity for V. americana (Figure 2a). Most ecotypes survived five weeks of exposure to 15.0 ppt salinity, but Caloosa, Snarrow, Feather, and STA did not (Table A3). These four ecotypes had very low growth rates across all salinity levels and, at $15.0 \mathrm{ppt}$, they lost shoots more quickly than they were able to replace via normal growth. When the rate of shoot loss increased, they failed to maintain enough photosynthesizing tissue and were decimated (Table A3). This is supported by research conducted by Munns [25], who reported that salt-stressed plants tend to accumulate salts in their older tissues, and, when salt concentration in old leaves reaches a toxic level, plants drop their "old" leaves and rely on new growth for photosynthesis. Prolonged salinity exposure could lead to a complete loss of photosynthesizing tissue and ultimately kill the plant. At $15.0 \mathrm{ppt}$, several other ecotypes such as Toho and Mann lost shoots at very high rates 
( -27 to $-15 \mathrm{mg} \mathrm{day}^{-1}$, respectively), but they accumulated enough photosynthesizing tissue to survive five weeks of $15.0 \mathrm{ppt}$ salinity exposure (Table A3). Bird and Trafford ecotypes had positive growth rates ( 5 to $25 \mathrm{mg} \mathrm{day}^{-1}$ ) at $15.0 \mathrm{ppt}$, which means that their biomass accumulation surpassed their leaf deterioration and shoot loss. Although this experiment ran for five weeks, one could expect that, at a given salinity, ecotypes with positive growth rate could tolerate longer salinity exposure (more than five weeks). However, the ability to endure longer salinity exposure does not necessarily make a species or ecotype salt tolerant.

It is suggested that salt tolerant species exhibit stimulated growth under increased salinity until salinity concentration reaches toxic level [26]. In our experiment, we observed that most ecotypes had higher growth and visual rating at $2.0 \mathrm{ppt}$ compared to $0.2 \mathrm{ppt}$ (no salt added) (Figure 2a,b). We could argue that an increase in growth at such a low salinity concentration (2.0 ppt) could be a hormetic response and not an indication of salt tolerance [16]. Hormesis is defined as the stimulation of growth by low levels of toxic compounds [27]. The aquarium salt mix used in this study has been shown to provide plants with macro and micronutrients such as calcium, sulfur, and magnesium, which reportedly help plant tolerate salinity stress [17]. At $2.0 \mathrm{ppt}$ concentration, these nutrients could enhance plant growth, provided the concentration of harmful compounds (e.g., sodium and chlorine) remain below toxic levels. Nevertheless, $2.0 \mathrm{ppt}$ salinity could have indirectly increased growth of $V$. americana by limiting growth of other competing organisms such as algae.

In our experiment, Bird had the highest growth rate among ecotypes and performed best under $15.0 \mathrm{ppt}$, for instance it had visual rating of 5.3 and growth rate of $25 \mathrm{mg} \mathrm{day}^{-1}$ at $15.0 \mathrm{ppt}$ which were only decreased by $53 \%$ and $32 \%$ compared to 2.0 ppt treatment. Reduced growth under salt stress is a common observation in salt-sensitive plants, yet the question remains whether high growth rate per se could impart salt tolerance. Lee et al. [28] used growth curves to study salt tolerance among Paspalum vaginatum ecotypes and suggested that, under salinity conditions, ecotypes with higher growth rates could be considered salt tolerant. Conflicting results were reported by Marcum and Murdoch [29], who found that salt tolerant ecotypes of P. vaginatum had lower growth rates than salt-sensitive ecotypes. In another example, salt-tolerant ecotypes of Arabidopsis used slow growth as a mechanism to better partition sodium into shoots and hence ecotypes with lower growth rates had greater ability for tolerating salt [30]. Rawson et al. [31] conducted an experiment on three species of barley, wheat, and triticale, and argued that greater growth under salinity conditions does not infer greater salt tolerance. They suggested that measuring high growth under the absence of salt is a better indicator of salt tolerance than growth rate under increased salinity.

In our experiment, STA and Feather ecotypes were ranked 15 and 20 for growth rate and died at $15.0 \mathrm{ppt}$, while ecotypes with lower growth rates such as Biven and Fairview (ranked 21 and 23 for growth rate, respectively) survived at $15.0 \mathrm{ppt}$. Consequently, lower growth rate does not translate to lower salt tolerance and high growth rate does not necessarily mean that a plant is salt-tolerant, but adequate growth may allow for potential recovery from salt injury [28].

In this study, visual ratings allowed us to accurately evaluate the health and survival of the plants, and dry weight data were used to calculate growth rate of each ecotype. Table 2 shows that $\mathrm{r}^{2}$ values for some $\mathrm{LC}_{\mathrm{d}}$ estimations were particularly low $\left(\mathrm{r}^{2}<0.50\right)$, which suggests that the regression curve explained less than $50 \%$ of the variability with dry weight data. However, $\mathrm{LC}_{\mathrm{v}}$ estimation on the same ecotype had much better fit to the visual rating data. This suggests that, under stress conditions, the health and visual quality of some ecotypes may decline as salinity increases, but their dry weight may not change correspondingly or with the same intensity. Although decayed plant material was removed before weighing plant samples, some dead materials retained their weight and could have contributed to the variability in dry weight data. For instance, there was a dramatic difference between estimated $\mathrm{LC}_{\mathrm{d}}(12.74)$ and $\mathrm{LC}_{\mathrm{v}}$ (4.14) values for Feather ecotype and $\mathrm{r}^{2}$ values for $\mathrm{LC}_{\mathrm{d}}$ and $\mathrm{LC}_{\mathrm{v}}$ were 0.16 and 0.89 , respectively, suggesting that the high $\mathrm{LC}_{\mathrm{d}}$ value was probably an overestimation. In this example, Feather was significantly impacted by salinity and its visual quality declined by $50 \%$ at 
$4.14 \mathrm{ppt}$, but its degraded mass retained a high weight, causing an overestimation in the $\mathrm{LC}_{\mathrm{d}}$ value (12.74 ppt) and its upper confidence interval (>20.0 ppt).

The ecotype that performed best based on overall rankings was Bird, with highest growth rate, and visual quality (Table 3). $\mathrm{LC}_{50}$ values indicated that Bird has an exceptional ability to grow under high-salinity conditions and loses half of its biomass only when salinity concentration is $9.10 \mathrm{ppt}$. High growth rate is critically important for restoration and revegetation project to succeed because introduced plants and transplants need to quickly establish at the target site to survive herbivory and competition with existing vegetation. Based on our results, the Bird ecotype could be a good candidate for restoration purposes because it had the highest growth rate among ecotypes (40 mg day $^{-1}$, on average) (Tables 3 and A2).

In this study, all environmental conditions such as sunlight, water depth, temperature, and salinity levels were equal among ecotypes, yet there were drastic differences in response to salinity treatments. For instance, Harris, with an overall ranking of 23, had a growth rate of $3 \mathrm{mg} \mathrm{day}^{-1}$, on average, which was $13 x$ and $5 x$ less than Bird's and George's growth rate, and Bird's growth rate was 2.5x higher than George (Table A2). Harris lost half its biomass at $0.80 \mathrm{ppt}\left(\mathrm{LC}_{\mathrm{d}}\right)$, which is 11-fold and 6-fold lower than the $\mathrm{LC}_{\mathrm{d}}$ values calculated for Bird and George ecotypes (Table 2). These drastic differences could be derived from differences in growth traits and biomass allocation, for example, production of stolons, roots, and other traits such as leaf elongation and leaf area [28,32]. Measuring these traits could provide valuable information for the comparison of ecotypes; however, it was not feasible for the scale of our experiment.

Previous research evaluating the effect of increased salinity on $V$. americana showed very similar results to this experiment; however, since it is common for researchers to use a single ecotype and thus are not able to report on the variability among ecotypes within the species. For example, research conducted on $V$. americana species in Florida reported a high rate of plant survival under $8.0 \mathrm{ppt}$ and complete elimination of aboveground biomass at $18.0 \mathrm{ppt}$ [11]. Other researchers have reported $6.0 \mathrm{ppt}$ [12] or $12.0 \mathrm{ppt}$ [33] as the maximum salinity level tolerable for V. americana. Therefore, reports for this species ranges between 5.0 to $15.0 \mathrm{ppt}[8,34,35]$. Few studies have compared the effect of salinity stress induced by $\mathrm{NaCl}$ to ocean water or aquarium salts [17,36], and reported that a $\mathrm{NaCl}$ solution can have $16 \%$ more sodium, which can reduce plant quality and growth more dramatically and at lower salinity level. Therefore, $\mathrm{LC}_{50}$ values estimated using different salt types may produce different results. Although research methodologies vary and ecotypes used in experiments are different, we can confirm that all V. americana ecotypes used in this study survived exposure to $10.0 \mathrm{ppt}$ salinity. Ecotypes may lose as much as $50 \%$ of their biomass upon exposure to $5.15 \mathrm{ppt}$ salinity concentration (on average), and 20 out of 24 ecotypes tolerated five weeks of exposure to $15.0 \mathrm{ppt}$. Salt tolerance thresholds reported in different experiments are highly dependent on the method of salinity induction/initiation (i.e., abrupt vs. gradual salinity increase), elemental composition of salt used (i.e., seawater vs. artificial salts), period/length of exposure [17,37], and the ecotype used in the experiment.

In this experiment, plants were exposed to continuous salinity stress, but, under field conditions, increased salinity can occur from saltwater intrusion or application of deicing salts and its intensity can vary based on the habitat, soil salinity, and seasonal precipitation. French and Moore [38] reported that $V$. americana survived at 10.0 to $15.0 \mathrm{ppt}$, but the same ecotype in the Chesapeake Bay region only occurs in salinities up to 5.0 ppt. In addition, Frazer [39] studied the effect of storm-induced tidal surges and other short-term variations in salinity on V. americana populations in Kings Bay, Florida and found that one to seven days of exposure to salinities of 15.0 or $25.0 \mathrm{ppt}$ significantly affected growth and survival of $V$. americana. Nevertheless, salt tolerance is a natural phenomenon with a complex mechanism. Sea level rise and saltwater intrusion impose pressure on plant populations to gradually evolve specialized population that can tolerate higher salinity conditions [7]. It is possible that ecotypes of $V$. americana with higher tolerance or sensitivity to salt could exist but were not included in our limited ecotype selection. 


\section{Conclusions}

Our results revealed that $V$. americana is significantly affected by increased salinity. Growth rate and visual quality ratings along the salinity gradient varied among ecotypes, which suggests that ecotypes respond differently to salt stress. Final dry weight measurement used for calculating growth rates was not as good as visual quality rating for assessment of plants under salt stress because stressed plants had discoloration or altered leaf shape, size and/or width, and growth rate is not able to detect such symptoms in plants. In addition, dead plants retain biomass, which may not correlate well with the level of stress that plants have experienced. Therefore, visual quality rating is a better indicator of plant health if performed properly. Ecotypes with lower growth rates did not die at lower salinity concentration; hence, growth rate per se is not the main determinant of salt tolerance, although the ecotype with the highest growth rate performed better than others.

Author Contributions: Conceptualization, M.T. and L.A.G.; Methodology, M.T., K.L.T., I.J.M., J.W.S., S.S., and L.A.G.; Software, M.T. and L.A.G.; Validation, M.T. and L.A.G., S.S.; Formal Analysis, M.T. and L.A.G.; Investigation, M.T. and L.A.G.; Resources, M.T., K.L.T. and L.A.G.; Data Curation, M.T.; Writing-Original Draft Preparation, M.T.; Writing—Review and Editing, M.T. and L.A.G.; Visualization, M.T.; Supervision, L.A.G; Project Administration, M.T.; Funding Acquisition, L.A.G. All authors have read and agreed to the published version of the manuscript.

Funding: This research was funded by the Florida Agricultural Experiment Station and by the United States Department of Agriculture National Institute of Food and Agriculture, (HATCH projects FLA-FTL-005156 and FLA-FTL-005682). Mention of a trademark, proprietary product or vendor does not constitute a guarantee or warranty of the product and does not imply its approval to the exclusion of other products or vendors that also may be suitable.

Acknowledgments: We would like to acknowledge our colleagues who helped us with acquiring the $V$. americana ecotype collection. The plant collection used in this study is available at the Fort Lauderdale Research and Education Center, University of Florida. Plant samples are available from the authors upon request.

Mention of a trademark, proprietary product or vendor does not constitute a guarantee or warranty of the product and does not imply its approval to the exclusion of other products or vendors that also may be suitable.

Conflicts of Interest: The authors declare no conflict of interest.

\section{Appendix A}

Table A1. Guideline for assigning visual quality scores to plants (0-10).

\begin{tabular}{cccc}
\hline Scale & Old Tissue & New/Young Tissue & Growth \\
\hline 10 & Green & Green & High growth \\
9 & Green & Green & High to moderate growth \\
8 & Green & Green & Moderate growth \\
7 & Green to yellow & Green & Low growth \\
6 & Green to yellow & Green & Low growth \\
5 & Yellow & Green to yellow & Very low to no growth \\
4 & Yellow & Yellow & No growth \\
3 & Yellow & Yellow & No growth \\
2 & Decaying old tissue & Yellow & No growth \\
1 & Decayed old tissue & Decaying new tissue & \\
0 & & Decayed, lost integrity & \\
\hline
\end{tabular}

Table A2. Visual rating (0-10) and growth rate $\left(\mathrm{mg} \mathrm{day}^{-1}\right)$ of each Vallisneria americana ecotype is compared under increased salinity condition. The control $(0.2 \mathrm{ppt})$ treatment is excluded from this analysis. Plants were assigned a visual quality score on a numerical scale of 0 through 10 , where $0=$ dead; and $10=$ excellent quality, perfect condition, healthy and robust. Growth rates were calculated using initial and final dry weights for the duration of the study.

\begin{tabular}{ccccc}
\hline Ecotype & \multicolumn{2}{c}{ Visual Rating } & $(\mathbf{0}-\mathbf{1 0})^{* *}$ & \multicolumn{2}{c}{ Growth Rate $\left(\mathrm{mg} \mathrm{day}^{\mathbf{- 1}}\right)^{* *}$} \\
\hline Bird & 6.8 & $\mathrm{~A}$ & 40 & $\mathrm{~A}$ \\
\hline
\end{tabular}


Table A2. Cont.

\begin{tabular}{|c|c|c|c|c|}
\hline \multirow{2}{*}{$\begin{array}{c}\text { Ecotype } \\
\text { George }\end{array}$} & \multicolumn{2}{|c|}{ Visual Rating $(0-10)^{* *}$} & \multicolumn{2}{|c|}{ Growth Rate $\left(\mathrm{mg} \text { day }^{-1}\right)^{* *}$} \\
\hline & 4.6 & BCD & 16 & $\mathrm{BC}$ \\
\hline Mann & 4.7 & $\mathrm{BC}$ & 10 & $\mathrm{BCD}$ \\
\hline Toho & 4.9 & $\mathrm{AB}$ & 9 & $\mathrm{BCDE}$ \\
\hline Monroe & 4.5 & $\mathrm{BCD}$ & 9 & $\mathrm{BCDE}$ \\
\hline Ballen & 4.8 & $\mathrm{~B}$ & 9 & $\mathrm{BCDE}$ \\
\hline Okeech & 4.2 & $\mathrm{BCD}$ & 8 & $\mathrm{BCDE}$ \\
\hline Trafford & 3.3 & BCDE & 7 & BCDE \\
\hline Kennedy & 4.9 & $\mathrm{AB}$ & 7 & $\mathrm{BCDE}$ \\
\hline Wekiva & 3.5 & BCDE & 4 & CDE \\
\hline Wakulla & 3.8 & $\mathrm{BCD}$ & 4 & CDE \\
\hline Rockstar & 4.1 & $\mathrm{BCD}$ & 4 & CDE \\
\hline Pierce & 3.4 & BCDE & 4 & CDE \\
\hline Harris & 2.8 & DEFG & 3 & CDE \\
\hline STA & 3.7 & BCDE & 3 & CDE \\
\hline Suwanee* & 2.8 & CDEFG & 2 & CDE \\
\hline Weekie & 3.2 & BCDEF & 2 & CDE \\
\hline Harney & 3.5 & BCDE & 1 & CDE \\
\hline Rainbow* & 1.7 & EFG & 1 & CDE \\
\hline Feather & 3.6 & BCDE & 0 & $\mathrm{DE}$ \\
\hline Biven & 4.5 & $\mathrm{BCD}$ & 0 & $\mathrm{DE}$ \\
\hline Snarrow ${ }^{*}$ & 1.0 & G & -1 & $\mathrm{DE}$ \\
\hline Fairview & 4.3 & $\mathrm{BCD}$ & -5 & $\mathrm{E}$ \\
\hline Caloosa* & 1.3 & FG & -5 & E \\
\hline
\end{tabular}

* Ecotype did not show a significant response to salinity gradient. ${ }^{* *}$ Means in a column with the same letter are not significantly different $(p>0.05)$.

Table A3. Effect of salinity on visual rating and growth rate of Vallisneria americana ecotypes.

\begin{tabular}{ccccccc}
\hline Ecotype & N & Df & \multicolumn{2}{c}{ Visual Rating } & \multicolumn{2}{c}{ Growth Rate } \\
& & & F Ratio & prob $>$ F & F Ratio & prob $>$ F \\
\hline Ballen & 5 & 5 & 38.06 & $<0.0001$ & 6.92 & 0.0009 \\
Bird & 5 & 5 & 36.89 & $<0.0001$ & 4.49 & 0.0079 \\
Biven & 5 & 5 & 5.99 & 0.002 & 3.59 & 0.0198 \\
Caloosa & 5 & 5 & 2.05 & $0.1262^{*}$ & 1.25 & $0.3314^{*}$ \\
Fairview & 5 & 5 & 12.3 & $<0.0001$ & 5.11 & 0.0048 \\
Feather & 5 & 5 & 59.27 & $<0.0001$ & 14.27 & $<0.0001$ \\
George & 5 & 5 & 125.1 & $<0.0001$ & 5.7 & 0.0029 \\
Harney & 5 & 5 & 17.14 & $<0.0001$ & 3.85 & 0.0163 \\
Harris & 5 & 5 & 17.55 & $<0.0001$ & 9.87 & 0.0001 \\
Kennedy & 5 & 5 & 151.93 & $<0.0001$ & 5.47 & 0.0031 \\
Mann & 5 & 5 & 13.11 & $<0.0001$ & 9.88 & 0.0001 \\
Monroe & 5 & 5 & 27.42 & $<0.0001$ & 7.61 & 0.0005 \\
Okeech & 5 & 5 & 74.65 & $<0.0001$ & 10.68 & $<0.0001$ \\
Pierce & 5 & 5 & 26.4 & $<0.0001$ & 3.04 & 0.0387 \\
Rainbow & 5 & 5 & 2.56 & $0.067^{*}$ & 1.57 & $0.2225^{*}$ \\
Rockstar & 5 & 5 & 10.78 & $<0.0001$ & 3.28 & 0.0281 \\
Snarrow & 5 & 5 & 2.41 & $0.0797^{*}$ & 1.74 & $0.1802^{*}$ \\
STA & 5 & 5 & 14.32 & $<0.0001$ & 1.97 & $0.1349^{*}$ \\
Suwanee & 5 & 5 & 3.82 & 0.0155 & 1.57 & $0.2199^{*}$ \\
Toho & 5 & 5 & 154.74 & $<0.0001$ & 14.59 & $<0.0001$ \\
Trafford & 5 & 5 & 7.26 & 0.0007 & 3 & 0.0383 \\
Wakulla & 5 & 5 & 8.37 & 0.0004 & 3.28 & 0.0297 \\
Weekie & 5 & 5 & 6.96 & 0.0009 & 6.59 & 0.0012 \\
Wekiva & 5 & 5 & 13.99 & $<0.0001$ & 3.24 & 0.0292 \\
\hline
\end{tabular}

* Ecotype did not show a significant response to salinity gradient based on standard least square analysis $(p<0.05)$. 
Table A4. Effect of salinity on visual rating and growth rate of Vallisneria americana ecotypes. Plants were assigned a visual quality score on a numerical scale of 0 (complete plant death) through 10 (no visible damage). Growth rate was calculated using the Hunt [18] method.

\begin{tabular}{|c|c|c|c|c|c|}
\hline \multirow{2}{*}{$\begin{array}{c}\text { Ecotype } \\
\text { Ballen }\end{array}$} & \multirow{2}{*}{$\begin{array}{c}\text { Salinity } \\
0.2\end{array}$} & \multicolumn{2}{|c|}{ Visual Rating (0-10) } & \multicolumn{2}{|c|}{ Growth Rate (mg day ${ }^{-1}$ ) } \\
\hline & & 9.00 & $\mathrm{~A}$ & 30 & $\mathrm{AB}$ \\
\hline Ballen & 2.0 & 9.00 & A & 42 & $\mathrm{~A}$ \\
\hline Ballen & 4.0 & 10.00 & $\mathrm{~A}$ & 26 & $\mathrm{AB}$ \\
\hline Ballen & 10.0 & 4.25 & $\mathrm{~B}$ & 4 & $\mathrm{ABC}$ \\
\hline Ballen & 15.0 & 0.75 & $\mathrm{C}$ & -8 & $\mathrm{BC}$ \\
\hline Ballen & 20.0 & 0.00 & $\mathrm{C}$ & -21 & $\mathrm{C}$ \\
\hline Bird & 0.2 & 9.00 & $\mathrm{~A}$ & 56 & A \\
\hline Bird & 2.0 & 10.00 & $\mathrm{~A}$ & 77 & $\mathrm{~A}$ \\
\hline Bird & 4.0 & 10.00 & A & 44 & $\mathrm{AB}$ \\
\hline Bird & 10.0 & 8.50 & A & 63 & A \\
\hline Bird & 15.0 & 5.25 & $\mathrm{~B}$ & 25 & $\mathrm{AB}$ \\
\hline Bird & 20.0 & 0.00 & $\mathrm{C}$ & -12 & B \\
\hline Biven & 0.2 & 5.75 & $\mathrm{AB}$ & -6 & $\mathrm{AB}$ \\
\hline Biven & 2.0 & 8.50 & $\mathrm{~A}$ & 15 & $\mathrm{~A}$ \\
\hline Biven & 4.0 & 8.00 & $\mathrm{~A}$ & 5 & $\mathrm{AB}$ \\
\hline Biven & 10.0 & 5.00 & $\mathrm{AB}$ & 4 & $\mathrm{AB}$ \\
\hline Biven & 15.0 & 1.00 & B & -8 & $\mathrm{AB}$ \\
\hline Biven & 20.0 & 0.00 & B & -17 & B \\
\hline Caloosa & 0.2 & 1.33 & $N S^{* *}$ & -4 & $\mathrm{NS}^{* *}$ \\
\hline Caloosa & 2.0 & 4.00 & NS & -4 & NS \\
\hline Caloosa & 4.0 & 1.50 & NS & -5 & NS \\
\hline Caloosa & 10.0 & 1.00 & NS & -5 & NS \\
\hline Caloosa & 15.0 & 0.00 & NS & -7 & NS \\
\hline Caloosa & 20.0 & 0.00 & NS & -7 & NS \\
\hline Fairview & 0.2 & 4.75 & $\mathrm{ABC}$ & -11 & $\mathrm{AB}$ \\
\hline Fairview & 2.0 & 7.67 & $\mathrm{AB}$ & 9 & $\mathrm{AB}$ \\
\hline Fairview & 4.0 & 9.25 & $\mathrm{~A}$ & 13 & $\mathrm{~A}$ \\
\hline Fairview & 10.0 & 4.00 & $\mathrm{BCD}$ & -7 & $\mathrm{AB}$ \\
\hline Fairview & 15.0 & 0.50 & $\mathrm{CD}$ & -20 & B \\
\hline Fairview & 20.0 & 0.00 & $\mathrm{D}$ & -20 & B \\
\hline Feather & 0.2 & 6.67 & A & 6 & $A B$ \\
\hline Feather & 2.0 & 8.00 & A & 1 & $\mathrm{BC}$ \\
\hline Feather & 4.0 & 7.75 & A & 3 & B \\
\hline Feather & 10.0 & 2.25 & B & 16 & A \\
\hline Feather & 15.0 & 0.00 & $\mathrm{C}$ & -9 & $\mathrm{C}$ \\
\hline Feather & 20.0 & 0.00 & $\mathrm{C}$ & -9 & $\mathrm{C}$ \\
\hline George & 0.2 & 10.00 & A & 45 & $\mathrm{AB}$ \\
\hline George & 2.0 & 10.00 & A & 62 & A \\
\hline George & 4.0 & 8.75 & A & 26 & $\mathrm{ABC}$ \\
\hline George & 10.0 & 3.33 & B & 12 & $\mathrm{ABC}$ \\
\hline George & 15.0 & 1.00 & $\mathrm{C}$ & -1 & $\mathrm{BC}$ \\
\hline George & 20.0 & 0.00 & $\mathrm{C}$ & -21 & $\mathrm{C}$ \\
\hline Harney & 0.2 & 5.25 & A & 1 & $A B$ \\
\hline Harney & 2.0 & 7.00 & A & 2 & $\mathrm{AB}$ \\
\hline Harney & 4.0 & 9.00 & A & 6 & $\mathrm{~A}$ \\
\hline Harney & 10.0 & 1.25 & B & 1 & $\mathrm{AB}$ \\
\hline Harney & 15.0 & 0.25 & B & -2 & B \\
\hline Harney & 20.0 & 0.00 & B & -3 & B \\
\hline Harris & 0.2 & 6.75 & $A B$ & 10 & $\mathrm{AB}$ \\
\hline Harris & 2.0 & 9.75 & $\mathrm{~A}$ & 20 & $\mathrm{~A}$ \\
\hline Harris & 4.0 & 2.75 & $\mathrm{BC}$ & -1 & B \\
\hline Harris & 10.0 & 1.00 & C & 1 & B \\
\hline Harris & 15.0 & 0.25 & $\mathrm{C}$ & -2 & B \\
\hline Harris & 20.0 & 0.00 & $\mathrm{C}$ & -2 & B \\
\hline
\end{tabular}


Table A4. Cont.

\begin{tabular}{|c|c|c|c|c|c|}
\hline \multirow{2}{*}{$\begin{array}{l}\text { Ecotype } \\
\text { Kennedy }\end{array}$} & \multirow{2}{*}{$\begin{array}{c}\text { Salinity } \\
0.2\end{array}$} & \multicolumn{2}{|c|}{ Visual Rating (0-10) } & \multicolumn{2}{|c|}{ Growth Rate (mg day ${ }^{-1}$ ) } \\
\hline & & 9.25 & A & 18 & $A B$ \\
\hline Kennedy & 2.0 & 9.75 & $\mathrm{~A}$ & 11 & A \\
\hline Kennedy & 4.0 & 9.25 & A & 32 & $\mathrm{AB}$ \\
\hline Kennedy & 10.0 & 4.50 & B & 10 & $\mathrm{AB}$ \\
\hline Kennedy & 15.0 & 1.00 & $\mathrm{C}$ & -2 & B \\
\hline Kennedy & 20.0 & 0.00 & $\mathrm{C}$ & -5 & B \\
\hline Mann & 0.2 & 7.50 & $\mathrm{~A}$ & 36 & $\mathrm{AB}$ \\
\hline Mann & 2.0 & 9.00 & A & 21 & $\mathrm{~A}$ \\
\hline Mann & 4.0 & 8.75 & A & 13 & $\mathrm{AB}$ \\
\hline Mann & 10.0 & 5.25 & $\mathrm{AB}$ & 8 & A \\
\hline Mann & 15.0 & 0.50 & $\mathrm{BC}$ & 0 & B \\
\hline Mann & 20.0 & 0.00 & $\mathrm{C}$ & -2 & B \\
\hline Monroe & 0.2 & 8.75 & A & 8 & $\mathrm{AB}$ \\
\hline Monroe & 2.0 & 8.50 & $\mathrm{~A}$ & 9 & $\mathrm{ABC}$ \\
\hline Monroe & 4.0 & 10.00 & A & 7 & A \\
\hline Monroe & 10.0 & 3.50 & B & 4 & $\mathrm{ABC}$ \\
\hline Monroe & 15.0 & 0.50 & B & 1 & BC \\
\hline Monroe & 20.0 & 0.00 & B & -1 & $\mathrm{C}$ \\
\hline Okeech & 0.2 & 10.00 & A & 0 & A \\
\hline Okeech & 2.0 & 8.00 & A & 4 & $A B$ \\
\hline Okeech & 4.0 & 10.00 & $\mathrm{~A}$ & 0 & $\mathrm{BC}$ \\
\hline Okeech & 10.0 & 2.75 & B & 0 & $\mathrm{BC}$ \\
\hline Okeech & 15.0 & 0.25 & $\mathrm{C}$ & 0 & $\mathrm{C}$ \\
\hline Okeech & 20.0 & 0.00 & $\mathrm{C}$ & -1 & $\mathrm{C}$ \\
\hline Pierce & 0.2 & 6.75 & A & 8 & A \\
\hline Pierce & 2.0 & 7.67 & $\mathrm{~A}$ & 5 & A \\
\hline Pierce & 4.0 & 7.25 & A & 13 & A \\
\hline Pierce & 10.0 & 1.50 & B & 12 & A \\
\hline Pierce & 15.0 & 0.50 & $\mathrm{~B}$ & -4 & A \\
\hline Pierce & 20.0 & 0.00 & B & -6 & A \\
\hline Rainbow & 0.2 & 2.75 & NS & -1 & NS \\
\hline Rainbow & 2.0 & 5.00 & NS & -2 & NS \\
\hline Rainbow & 4.0 & 2.00 & NS & 1 & NS \\
\hline Rainbow & 10.0 & 0.75 & NS & -2 & NS \\
\hline Rainbow & 15.0 & 0.75 & NS & -2 & NS \\
\hline Rainbow & 20.0 & 0.00 & NS & -2 & NS \\
\hline Rockstar & 0.2 & 7.50 & $\mathrm{AB}$ & 9 & $\mathrm{~A}$ \\
\hline Rockstar & 2.0 & 7.00 & $\mathrm{AB}$ & 4 & A \\
\hline Rockstar & 4.0 & 9.75 & $\mathrm{~A}$ & 8 & A \\
\hline Rockstar & 10.0 & 3.25 & $\mathrm{BC}$ & 7 & A \\
\hline Rockstar & 15.0 & 0.50 & $\mathrm{C}$ & 0 & A \\
\hline Rockstar & 20.0 & 0.00 & $\mathrm{C}$ & -4 & A \\
\hline Snarrow & 0.2 & 1.50 & NS & 2 & NS \\
\hline Snarrow & 2.0 & 0.33 & NS & 3 & NS \\
\hline Snarrow & 4.0 & 4.25 & NS & 9 & NS \\
\hline Snarrow & 10.0 & 0.25 & NS & 0 & NS \\
\hline Snarrow & 15.0 & 0.00 & NS & 2 & NS \\
\hline Snarrow & 20.0 & 0.00 & NS & -3 & NS \\
\hline STA & 0.2 & 5.25 & $\mathrm{AB}$ & 18 & NS \\
\hline STA & 2.0 & 7.75 & $\mathrm{~A}$ & 54 & NS \\
\hline STA & 4.0 & 8.67 & $\mathrm{~A}$ & 23 & NS \\
\hline STA & 10.0 & 2.00 & $\mathrm{BC}$ & 23 & NS \\
\hline STA & 15.0 & 0.00 & $\mathrm{C}$ & -27 & NS \\
\hline STA & 20.0 & 0.00 & $\mathrm{C}$ & -27 & NS \\
\hline Suwanee & 0.2 & 3.50 & NS & -11 & NS \\
\hline Suwanee & 2.0 & 6.50 & NS & 28 & NS \\
\hline Suwanee & 4.0 & 5.75 & NS & 15 & NS \\
\hline
\end{tabular}


Table A4. Cont.

\begin{tabular}{|c|c|c|c|c|c|}
\hline \multirow{2}{*}{$\begin{array}{c}\text { Ecotype } \\
\text { Suwanee }\end{array}$} & \multirow{2}{*}{$\begin{array}{c}\text { Salinity } \\
10.0\end{array}$} & \multicolumn{2}{|c|}{ Visual Rating (0-10) } & \multicolumn{2}{|c|}{ Growth Rate (mg day ${ }^{-1}$ ) } \\
\hline & & 0.75 & NS & 0 & NS \\
\hline Suwanee & 15.0 & 1.00 & NS & 5 & NS \\
\hline Suwanee & 20.0 & 0.00 & NS & -11 & NS \\
\hline Toho & 0.2 & 9.25 & A & 7 & A \\
\hline Toho & 2.0 & 10.00 & A & 32 & $\mathrm{~A}$ \\
\hline Toho & 4.0 & 10.00 & A & -4 & $\mathrm{~A}$ \\
\hline Toho & 10.0 & 3.75 & $\mathrm{~B}$ & 8 & $\mathrm{~A}$ \\
\hline Toho & 15.0 & 0.50 & $\mathrm{C}$ & -4 & $\mathrm{~B}$ \\
\hline Toho & 20.0 & 0.00 & $\mathrm{C}$ & -11 & $\mathrm{~B}$ \\
\hline Trafford & 0.2 & 7.25 & $\mathrm{AB}$ & 7 & A \\
\hline Trafford & 2.0 & 6.75 & $\mathrm{AB}$ & 11 & A \\
\hline Trafford & 4.0 & 7.75 & A & 5 & A \\
\hline Trafford & 10.0 & 1.50 & $\mathrm{BC}$ & 0 & $\mathrm{~A}$ \\
\hline Trafford & 15.0 & 0.50 & $\mathrm{C}$ & -3 & A \\
\hline Trafford & 20.0 & 0.00 & $\mathrm{C}$ & -3 & $\mathrm{~A}$ \\
\hline Wakulla & 0.2 & 6.50 & $A B$ & 10 & $\mathrm{AB}$ \\
\hline Wakulla & 2.0 & 9.67 & A & 20 & A \\
\hline Wakulla & 4.0 & 5.00 & $\mathrm{ABC}$ & 7 & $\mathrm{AB}$ \\
\hline Wakulla & 10.0 & 2.25 & $\mathrm{BC}$ & -1 & $\mathrm{AB}$ \\
\hline Wakulla & 15.0 & 2.00 & $\mathrm{BC}$ & -1 & $\mathrm{AB}$ \\
\hline Wakulla & 20.0 & 0.00 & $\mathrm{C}$ & -4 & $\mathrm{~B}$ \\
\hline Weekie & 0.2 & 6.00 & $A B$ & 30 & $\mathrm{AB}$ \\
\hline Weekie & 2.0 & 8.00 & $\mathrm{~A}$ & 42 & A \\
\hline Weekie & 4.0 & 6.25 & $\mathrm{AB}$ & 26 & $\mathrm{ABC}$ \\
\hline Weekie & 10.0 & 1.25 & $\mathrm{BC}$ & 4 & $\mathrm{BC}$ \\
\hline Weekie & 15.0 & 0.50 & $\mathrm{BC}$ & -8 & $\mathrm{BC}$ \\
\hline Weekie & 20.0 & 0.00 & $\mathrm{C}$ & -21 & $\mathrm{C}$ \\
\hline Wekiva & 0.2 & 7.25 & A & 56 & $\mathrm{AB}$ \\
\hline Wekiva & 2.0 & 9.25 & A & 77 & $\mathrm{~A}$ \\
\hline Wekiva & 4.0 & 6.25 & A & 44 & $\mathrm{AB}$ \\
\hline Wekiva & 10.0 & 1.00 & B & 63 & $\mathrm{AB}$ \\
\hline Wekiva & 15.0 & 0.75 & B & 25 & $\mathrm{AB}$ \\
\hline Wekiva & 20.0 & 0.00 & B & -12 & B \\
\hline
\end{tabular}

Means in a column with the same letter are not significantly different $(p<0.05)$. NS** Ecotype did not show a significant response $(p>0.05)$ to salinity gradient based on standard least square analysis.

\section{References}

1. Lowry, D.B.; Hall, M.C.; Salt, D.E.; Willis, J.H. Genetic and physiological basis of adaptive salt tolerance divergence between coastal and inland Mimulus guttatus. New Phytol. 2009, 776, 776-788. [CrossRef] [PubMed]

2. Van Wijk, R.J.; Van Goor, E.M.J.; Verkley, J.A.C. Ecological studies on Potamogeton pectinatus L. II. Autecological characteristics, with emphasis on salt tolerance, intraspecific variation and isoenzyme patterns. Aquat. Bot. 1988, 32, 239-260. [CrossRef]

3. Hester, M.W.; Mendelssohn, I.A.; Mckee, K.L. Intraspecific variation in salt tolerance and morphology in the coastal grass spartina patens (poaceae). Am. J. Bot. 1996, 83, 1521-1527. [CrossRef]

4. Hester, M.W.; Mendelssohn, I.A.; Mckee, K.L. Intraspecific variation in salt tolerance and morphology in Panicum hemitomon and Spartina alterniflora (Poaceae). Int. J. Plant Sci. 1998, 159, 127-138. [CrossRef]

5. Howard, R.J.; Rafferty, P.S. Clonal variation in response to salinity and flooding stress in four marsh macrophytes of the northern Gulf of Mexico, USA. Environ. Exp. Bot. 2006, 56, 301-313. [CrossRef]

6. Pezeshki, S.; DeLaune, R.D. Ecophenic variations in wiregrass (Spartina patens). J. Aquat. Plant Manag. 1991, 29, 99-102.

7. Pezeshki, S.; DeLaune, R.D. Variations in response of two US Gulf Coast populations of Spartina alterniflora to hypersalinity. J. Coast. Res. 1995, 11, 89-95. 
8. Tootoonchi, M.; Gettys, L.A.; Bhadha, J.H. Tapegrass, Eelgrass, or Wild Celery (Vallisneria americana Michaux): A Native Aquatic and Wetland Plant; University of Florida Institute of Food and Agricultural Sciences, EDIS: Gainesville, FL, USA, 2019.

9. Lauer, N.; Yeager, M.; Kahn, A.E.; Dobberfuhl, D.R.; Ross, C. The effects of short term salinity exposure on the sublethal stress response of Vallisneria americana Michx. (Hydrocharitaceae). Aquat. Bot. 2011, 95, 207-213. [CrossRef]

10. Salter, J.; Morris, K.; Boon, P.I. Does salinity reduce the tolerance of two contrasting wetland plants, the submerged monocot Vallisneria australis and the woody shrub Melaleuca ericifolia, to wetting and drying? Mar. Freshw. Res. 2008, 59, 291. [CrossRef]

11. Boustany, R.G.; Michot, T.C.; Moss, R.F. Effects of salinity and light on biomass and growth of Vallisneria americana from Lower St. Johns River, FL, USA. Wetl. Ecol. Manag. 2010, 18, 203-217. [CrossRef]

12. Haller, W.T.; Sutton, D.L.; Barlowe, W.C. Effects of salinity on growth of several aquatic macrophytes. Ecology 1974, 55, 891-894. [CrossRef]

13. Mazzotti, F.J.; Pearlstine, L.G.; Chamberlain, R.H.; Hunt, M.J. Stressor response model for Tape Grass (Vallisneria americana). Doc. CIR 2008, 3, 1-11.

14. Gettys, L.A.; Haller, W.T. Notes Effect of ecotype, sediment composition, and fertility level on productivity of eight Florida ecotypes of American eelgrass (Vallisneria americana). J. Aquat. Plant Manag. 2013, 51, 127-131.

15. Rodriguez, A.F.; Serna, A.; Scinto, L.J. Soil accretion influenced by elevation, tree density, and substrate on reconstructed tree islands. Soil Sci. Soc. Am. J. 2014, 78, 2090-2099. [CrossRef]

16. Poschenrieder, C.; Cabot, C.; Martos, S.; Gallego, B.; Barceló, J. Do toxic ions induce hormesis in plants? Plant Sci. 2013, 212, 15-25. [CrossRef]

17. Tootoonchi, M.; Gettys, L.A. Testing salt stress on aquatic plants: Effect of salt source and substrate. Aquat. Ecol. 2019, 53, 325-334. [CrossRef]

18. Hunt, R. Absolute growth rates. In Basic Growth Analysis; Springer: Dordrecht, The Netherlands, 1990; pp. 17-24.

19. Archontoulis, S.V.; Miguez, F.E. Nonlinear regression models and applications in agricultural research. Agron. J. 2015, 107, 786. [CrossRef]

20. Moore, D.R.J.; Caux, P.-Y. Estimating low toxic effects. Environ. Toxicol. Chem. 1997, 16, 794-801. [CrossRef]

21. Gettys, L.; Haller, W. Tolerance of selected bedding plants to four herbicides in irrigation water. Horttechnology 2009, 19, 546-552. [CrossRef]

22. Stephenson, G.L.; Koper, N.; Atkinson, G.F.; Solomon, K.R.; Scroggins, R.P. Use of nonlinear regression techniques for describing concentration-response relationships of plant species exposed to contaminated site soils. Environ. Toxicol. Chem. 2000, 19, 2968-2981. [CrossRef]

23. Munns, R.; Termaat, A. Whole-plant responses to salinity. Funct. Plant Biol. 1986, 13, 143-160. [CrossRef]

24. Shavrukov, Y. Salt stress or salt shock: Which genes are we studying? J. Exp. Bot. 2013, 64, 119-127. [CrossRef] [PubMed]

25. Munns, R. Comparative physiology of salt and water stress. Plant Cell Environ. 2002, 25, 239-250. [CrossRef] [PubMed]

26. Colmer, T.D.; Flowers, T.J. Flooding tolerance in halophytes. New Phytol. 2008, 179, 964-974. [CrossRef] [PubMed]

27. Stebbing, A.R.D. Hormesis-The stimulation of growth by low levels of inhibitors. Sci. Total Environ. 1982, 22, 213-234. [CrossRef]

28. Lee, G.; Carrow, R.N.; Duncan, R.R. Photosynthetic responses to salinity stress of halophytic seashore paspalum ecotypes. Plant Sci. 2004, 166, 1417-1425. [CrossRef]

29. Marcum, K.B.; Murdoch, C.L. Salinity tolerance mechanisms of six C4 turfgrasses. J. Am. Soc. Hortic. Sci. 1994, 119, 779-784. [CrossRef]

30. Jha, D.; Shirley, N.; Tester, M.; Roy, S.J. Variation in salinity tolerance and shoot sodium accumulation in Arabidopsis ecotypes linked to differences in the natural expression levels of transporters involved in sodium transport. Plant Cell Environ. 2010, 33, 793-804.

31. Rawson, H.M.; Richards, R.A.; Munns, R. An examination of selection criteria for salt tolerance in wheat, barley and triticale genotypes. Aust. J. Agric. Res. 1988, 39, 759-772. [CrossRef]

32. Munns, R.; James, R.A. Screening methods for salinity tolerance: A case study with tetraploid wheat. Plant Soil 2003, 253, 201-218. [CrossRef] 
33. Twilley, R.R.; Barko, J.W. The growth of submersed macrophytes under experimental salinity and light conditions. Estuaries 1990, 13, 311-321. [CrossRef]

34. Kraemer, G.P.; Chamberlain, R.H.; Doering, P.H.; Steinman, A.D.; Hanisak, M.D. Physiological responses of transplants of the freshwater angiosperm Vallisneria americana along a salinity gradient in the Caloosahatchee Estuary (Southwestern Florida). Estuaries 1999, 22, 138-148. [CrossRef]

35. Mcfarland, D.G. Reproductive Ecology of Vallisneria Americana Michaux; US Army Engineer Researach and Development Center: Vicksburg, MS, USA, 2006.

36. Zalizniak, L.; Kefford, B.J.; Nugegoda, D. Is all salinity the same? The effect of ionic compositions on the salinity tolerance of five species of freshwater invertebrates. Mar. Freshw. Res. 2006, 57, 75-82. [CrossRef]

37. Doering, P.H.; Chamberlain, R.H.; Mcmunigal, J.M. Effects of simulated saltwater intrusions on the growth and survival of Wild Celery, Vallisneria americana, from the Caloosahatchee Estuary (South Florida). Estuar. Res. Fed. Estuaries 2001, 894, 894-903. [CrossRef]

38. French, G.T.; Moore, K.A. Interactive effects of light and salinity stress on the growth, reproduction, and photosynthetic capabilities of Vallisneria americana (wild celery). Estuaries 2003, 26, 1255-1268. [CrossRef]

39. Frazer, T.K.; Notestein, S.K.; Jacoby, C.A.; Littles, C.J.; Keller, S.R.; Swett, R.A. Effects of storm-induced salinity changes on submersed aquatic vegetation in Kings Bay, Florida. Estuaries Coasts 2006, 29, 943-953. [CrossRef]

(C) 2020 by the authors. Licensee MDPI, Basel, Switzerland. This article is an open access article distributed under the terms and conditions of the Creative Commons Attribution (CC BY) license (http://creativecommons.org/licenses/by/4.0/). 